\title{
Maned wolves retain moderate levels of genetic diversity and gene flow despite drastic habitat fragmentation
}

\author{
Natalia Mannise ${ }^{1, *}$, Mariana Cosse ${ }^{1}$, Susana González ${ }^{1,2}$, Louise H. Emmons ${ }^{3}$, \\ José Mauricio Barbanti Duarte ${ }^{4}$, Marcelo D. Beccaceci ${ }^{5}$, Jesús E. Maldonado ${ }^{6}$ \\ ${ }^{1}$ Genética de la Conservación, Departamento de Biodiversidad y Genética, Instituto de Investigaciones Biológicas Clemente \\ Estable (IIBCE), Montevideo 11600, Uruguay \\ ${ }^{2}$ Sección Genética Evolutiva, Facultad de Ciencias, Universidad de la República (UdelaR), Montevideo 11400, Uruguay \\ ${ }^{3}$ Department of Vertebrate Zoology, National Museum of Natural History, Smithsonian Institution, Washington, DC 20013, USA \\ ${ }^{4}$ Núcleo de Pesquisa e Conservação de Cervídeos, Departamento de Zootecnia, Universidade Estadual Paulista, Jaboticabal, \\ 14884-900 SP, Brazil \\ ${ }^{5}$ Ministerio de Ambiente y Desarrollo Sustentable, Buenos Aires 1004, Argentina \\ ${ }^{6}$ Center for Conservation Genomics, Smithsonian Conservation Biology Institute, National Zoological Park, Washington, \\ DC 20008, USA
}

\begin{abstract}
The maned wolf Chrysocyon brachyurus is the largest South American canid and categorized as Near Threatened on the IUCN Red List. The major threat to conservation efforts is the drastic reduction of suitable habitat for the species. A large portion of its range has been converted into farm and ranch lands as well as urban areas. To better understand the impact that these anthropogenic activities are having over the remaining populations across their current distribution range, we evaluated patterns of genetic variability and differentiation between them. We also compared these results with those obtained from captive maned wolves in order to make proper ex situ recommendations. We cross-amplified 12 microsatellite loci in maned wolf samples collected throughout their range (from Argentina, Brazil, Uruguay and Bolivia) and from captive stocks (from captive breeding centers and zoos in Brazil, Argentina and the USA). We found that wild populations retain moderate levels of genetic variability compared with other microsatellite studies on wild canids, and our structure analysis revealed 2 genetic clusters in wild samples, one of which included samples exclusively from Bolivia. This cluster could represent a different management unit with conservation priority. The captive stock population showed higher levels of genetic variability, with the ones from Brazil being the most genetically diverse stock. The USA stock showed strong genetic differences with all other groups. This is the first study to examine the patterns of genetic diversity of both wild and captive populations of maned wolves. These results should be incorporated into further population viability assessments and in the Maned Wolf Species Survival Plan.
\end{abstract}

KEY WORDS: Canids $\cdot$ Population genetics $\cdot$ Microsatellite loci $\cdot$ Noninvasive genetic analysis

\section{INTRODUCTION}

The maned wolf Chrysocyon brachyurus is a Neotropical canid that is restricted to open areas in the Cerrado, Chaco and Pampas regions of Argentina,

\footnotetext{
*Corresponding author: natymanni@gmail.com
}

Bolivia, Brazil, Paraguay, Peru and Uruguay (Dietz 1985, Queirolo et al. 2011). It is classified as Near Threatened on the IUCN Red List, with 17000 mature individuals estimated in the current global population (Paula \& DeMatteo 2016). The major (c) N.M., M.C., S.G., L.H.E., J.M.B.D., M.D.B., and outside the USA, the US Government 2017. Open Access under Creative Commons by Attribution Licence. Use, distribution and reproduction are unrestricted. Authors and original publication must be credited. 
threat to its conservation is the loss of suitable habitat because a large portion of its distribution has been converted into farm and ranch lands (De Paula et al. 2008). Currently, anthropogenic changes have affected maned wolf distribution patterns and resulted in demographic contractions and expansions (De Paula \& DeMatteo 2016). Due to their large home ranges and their mainly solitary behavior, maned wolves are generally found in low densities throughout their range (Rodden et al. 2004). Other human-related threats include urbanization and mortality from road kills and diseases transmitted by domestic dogs (Rodden et al. 2004, Deem \& Emmons 2005, De Paula et al. 2008, De Paula \& DeMatteo 2016). Together, these factors are influencing the decline and reduction of the current global population, with subsequent demographic and genetic instability resulting in local population extinction (De Paula et al. 2008).

Analysis of genetic variation can provide essential information about population history and demography, which is relevant for endangered species management (Bos et al. 2008). The first genetic studies on maned wolves were conducted mostly on Brazilian populations, reporting levels of heterozygosity around 0.7 and no genetic signatures of geographic structure (Rodrigues et al. 2006, Salim et al. 2007, FontouraRodrigues et al. 2008, Prates 2008, Do Passo Ramalho 2011, Lion et al. 2011, Do Passo Ramalho et al. 2014).

Those studies were done on a local scale, but to properly assess the impact of more recent anthropogenic pressure, evaluate genetic structure, and compare genetic diversity among different maned wolf populations, a broad-scale sampling across the species' range is required (Fontoura-Rodrigues \& Eizirik 2014). A recent study looking at maned wolf phylogeographic patterns based solely on mtDNA (González et al. 2015a) found moderate levels of haplotype and nucleotide diversity, and genetic structure was partitioned into 4 groups. This suggested that maned wolves underwent demographic fluctuations due to changes in climate and habitat during the Pleistocene glaciation period approximately $24000 \mathrm{yr}$ before present (BP) (González et al. 2015a). However, the authors were unable to make definitive conservation management recommendations because they lacked evidence from nuclear markers, and they recommended that future genetic studies should focus on increasing the number of individuals and populations sampled with additional variable nuclear markers. Because González et al. (2015a) based their study on single-locus evidence from maternally inherited mtDNA, it was not possible to assess whether members of the different mitochondrial genetic line- ages interbreed with each other. Microsatellite markers are among the markers of choice to study finescale variation in endangered species populations. They are commonly used to assess population genetic structure and they can also provide valuable information to define management units for short-term management of populations (Moritz 1994, 1995, 1999, Hedrick 2001, Wayne \& Morin 2004, Palsbøll et al. 2007). In the present study, we aimed to evaluate the current patterns of genetic structure in maned wolf wild populations by including samples from wild animals throughout the species range with a suite of 12 polymorphic microsatellite loci. We compared our results with those obtained in a previous study based on mtDNA (González et al. 2015a). We also analyzed samples from captive maned wolves to compare them to the wild population. Our results are pertinent for design guidelines for the genetic management of both wild and captive maned wolves.

\section{MATERIALS AND METHODS}

\section{Sampling}

We collected 61 samples from wild Chrysocyon brachyurus from Argentina, Brazil, Bolivia and Uruguay (Table 1, see Fig. 1A). In Brazil, samples were collected from captive animals that were taken from the wild from known capture localities (Table 1). We included 2 Uruguayan tissue samples from animals that were killed by poachers (specimens deposited in the National Museum of Natural History, Montevideo). One was from an individual killed in 1989 in Río Negro Department, and the other was from Cerro Largo Department in 2006. A few days after the poaching episode in the Department of Cerro Largo, a scat was collected in the same locality (Mannise et al. 2012). Most samples from Argentina were tissues from freshly road-killed animals, and samples from Bolivia were either blood from animals captured in the wild or fecal samples collected over several sampling surveys (Emmons 2012); all Bolivian samples were from the same small population of a few family groups (Table 1).

A total of 27 samples from captive maned wolves were collected from hair $(n=16)$ and blood $(n=11)$ of animals kept in different zoos and captive breeding centers. Based on the sample number and exchange of breeding stock between different zoos within a country or region, we defined 3 captive stocks: Argentina (La Plata and Buenos Aires zoos, $\mathrm{n}=10$ ), Brazil (Riberao Preto and Belo Horizonte zoos, $n=11$ ) 
Table 1. Samples obtained from wild populations of Chrysocyon brachyurus from Argentina, Bolivia, Brazil and Uruguay. $\mathrm{n}=$ number of samples

\begin{tabular}{|c|c|c|c|c|c|c|}
\hline \multirow[t]{2}{*}{ Country } & \multirow[t]{2}{*}{ Locality } & \multirow[t]{2}{*}{ Geographic coordinates } & \multicolumn{4}{|c|}{-Sample type (n)- } \\
\hline & & & Hair & Blood & Tissue & Feces \\
\hline \multirow[t]{4}{*}{ Argentina } & Chaco & $26^{\circ} 12^{\prime}$ to $26^{\circ} 47^{\prime} \mathrm{S}, 59^{\circ} 43^{\prime}$ to $60^{\circ} 47^{\prime} \mathrm{W}$ & & 2 & 6 & \\
\hline & Santa Fe & $30^{\circ} 14^{\prime} \mathrm{S}, 60^{\circ} 47^{\prime} \mathrm{W}$ & & & 1 & \\
\hline & Santiago del Estero & $27^{\circ} 49^{\prime} \mathrm{S}, 63^{\circ} 08^{\prime} \mathrm{W}$ & & 1 & & \\
\hline & Formosa & $25^{\circ} 09^{\prime} \mathrm{S}, 59^{\circ} 35^{\prime} \mathrm{W}$ & & & 2 & \\
\hline \multirow[t]{3}{*}{ Bolivia } & $\begin{array}{l}\text { Los Fierros camp, } \\
\text { Noel Kempff Mercado National Park }\end{array}$ & $14^{\circ} 33^{\prime} \mathrm{S}, 60^{\circ} 55^{\prime} \mathrm{W}$ & & 5 & & 23 \\
\hline & Mangabalito & $13^{\circ} 47^{\prime} \mathrm{S}, 60^{\circ} 32^{\prime} \mathrm{W}$ & & 1 & & \\
\hline & El Refugio & $14^{\circ} 47^{\prime} \mathrm{S}, 61^{\circ} 02^{\prime} \mathrm{W}$ & & & & 8 \\
\hline \multirow[t]{4}{*}{ Brazil } & Franca & $20^{\circ} 32^{\prime} \mathrm{S}, 47^{\circ} 21^{\prime} \mathrm{W}$ & 1 & & 3 & \\
\hline & Chapada Do Sul & $18^{\circ} 27^{\prime} \mathrm{S}, 52^{\circ} 36^{\prime} \mathrm{W}$ & & & 1 & \\
\hline & Yatai & $17^{\circ} 05^{\prime} \mathrm{S}, 51^{\circ} 26^{\prime} \mathrm{W}$ & & & 1 & \\
\hline & Gaia & $20^{\circ} 11^{\prime} \mathrm{S}, 47^{\circ} 25^{\prime} \mathrm{W}$ & 3 & & & \\
\hline \multirow[t]{2}{*}{ Uruguay } & Río Negro Department & $32^{\circ} 35^{\prime} 45^{\prime \prime} \mathrm{S}, 58^{\circ} 08^{\prime} 46^{\prime \prime} \mathrm{W}$ & & & 1 & \\
\hline & Cerro Largo Department & $32^{\circ} 14^{\prime} 43^{\prime \prime} \mathrm{S}, 54^{\circ} 03^{\prime} 30^{\prime \prime} \mathrm{W}$ & & & 1 & 1 \\
\hline
\end{tabular}

and USA (National Zoological Park [NZP], Smithsonian Institution, Front Royal, VA, $\mathrm{n}=6$ ). The NZP samples were from a family group composed of both parents (descendants of animals captured in Brazil) and 4 offspring (N. Songsasen, pers. comm.). Most of the Brazilian stock originated from the central and southeastern areas of the country (Vanstreels \& Pessutti 2010).

\section{DNA extractions and genotyping}

DNA was extracted from hair, blood and tissue samples following the protocol of González et al. (2015b) or using a DNeasy kit (Qiagen). Fecal DNA extractions were performed using a QIAamp DNA Stool Mini Kit (Qiagen) with sterile materials and filtered pipette tips in a room dedicated for DNA extraction from low-quality samples and separate from PCR product contamination. Extraction negative controls and no-template PCR controls were used in each reaction.

Twelve microsatellite loci, originally designed for domestic dog, were selected on the basis of polymorphism level, reliable amplification and easy scorability in several canid species (Franco Berriel 2004, Smith et al. 2006, Salim et al. 2007, Fontoura-Rodrigues et al. 2008, Lion et al. 2011, Do Passo Ramalho et al. 2014). Based on annealing temperature, fragment size and fluorochrome label, we designed 4 PCR multiplexes. Each reaction consisted of a total volume of

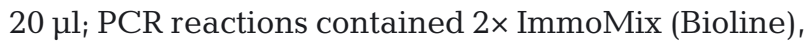
$0.75 \mu \mathrm{M}$ of each primer and $80 \mathrm{ng}$ of genomic DNA (McKelvey 2008). The thermal profile included an initial denaturation step of $95^{\circ} \mathrm{C}$ for $10 \mathrm{~min}$, followed by 35 cycles of $95^{\circ} \mathrm{C}$ for $30 \mathrm{~s}$, annealing temperature for $1 \mathrm{~min}, 72^{\circ} \mathrm{C}$ for $1 \mathrm{~min}$, and finally an extension step of $72^{\circ} \mathrm{C}$ for $15 \mathrm{~min}$. Amplified products were run with a LIZ 500 size standard on an ABI PRISM 3100 automated sequencer. Migration was performed in a $22 \mathrm{~cm}$ capillary array using POP4 polymer (Applied Biosystems) with the following parameters: $100 \mathrm{~A}$, $15 \mathrm{kV}$, and $60^{\circ} \mathrm{C}$ for $35 \mathrm{~min}$.

Fragment size was examined using GENESCAN ANALYSIS ${ }^{\circledR}$ (Applied Biosystems) software at the Center for Conservation Genomics, Smithsonian Conservation Biology Institute, NZP. Genotyping was conducted using GENOTYPER (Applied Biosystems) and GENEMARKER v.1.75 (SoftGenetics).

For noninvasive samples, we conducted multiple replicates for each sample and locus following a multi-tube approach to identify and minimize genotyping errors such as allelic dropout and false alleles (Navidi et al. 1992, Taberlet et al. 1996, 1999). We used duplicated genotypes for heterozygotes and triplicated for homozygotes.

\section{Genetic analyses}

Genotyping errors caused by the presence of null alleles, allelic dropout or stutter were screened using MICRO-CHECKER software (Van Oosterhout et al. 2004) following Brookfield's (1996) estimation. Standard genetic parameters were estimated for the captive and wild sample datasets independently. We assessed allele and genotype frequencies using GENEPOP (Raymond \& Rousset 1995). Polymorphic 
information content (PIC), non-exclusion probability for parent pairs (NE-PP) and for the identity (NE-I) and sibling identity (NE-SI), were calculated by CERVUS v.3.0 (Marshall et al. 1998). Allelic richness (AR) was computed by the rarefaction method with HP-RARE software (Kalinowski 2005). This method is recommended for standardizing the AR for comparing populations of unequal sample sizes (Kalinowski 2005). In order to compare the genetic variability in different populations, a $t$-test for unpaired populations was calculated using AR and observed heterozygosity $\left(H_{0}\right)$ values in Gnumeric Spreadsheet v.1.10.16 (www.gnumeric.org). We conducted tests for Hardy-Weinberg equilibrium (HWE) and linkage disequilibrium (LD) using GENEPOP (Raymond \& Rousset 1995). Genotypic disequilibrium was tested using Bonferroni corrections (Rice 1989).

\section{Genetic structure and differentiation}

Wild populations

We explored the pattern of genetic structure using the Bayesian clustering method implemented in STRUCTURE software (Pritchard et al. 2000). This widely used approach assigns individuals into $K$ clusters in a way that minimizes deviations from HWE and LD within each cluster. The program uses a Markov chain Monte Carlo (MCMC) procedure to estimate the posterior probability that the data fit the hypothesis of $K$ clusters. The program also calculates the fractional membership of each individual in each cluster (q). We tested $K$ ranging from 1 to 10 with 5 replicates using the admixture model, a burn-in period of 10000 and 200000 iterations for MCMC runs. We conducted the STRUCTURE analysis with 2 datasets: one included all individuals from Bolivia, and the other excluded individuals from Bolivia that showed relatedness coefficients (r) higher than 0.25 between each other. The relatedness coefficients were calculated with ML-Relate software (Kalinowski et al. 2006). The most likely number of clusters was selected using the posterior probability of the data $(\ln \mathrm{P}(K))$ and the second-order rate of change of log probability (Delta $K$ ) (Evanno et al. 2005) in the program STRUCTURE HARVESTER v.0.6.8 (Earl \& vonHoldt 2012). The differentiation between clusters was evaluated with $F_{\mathrm{ST}}$ and its statistical significance by FSTAT v.2.9.3 (Goudet 1995). We estimated the effective number of migrants between clusters according to Slatkin (1985) by the private allele method using GENEPOP v.4.0.10 (Raymond \& Rousset 1995) and also indirectly calculated it with Wright's $F_{\mathrm{ST}}$ estimator (Wright 1943, Cegelski et al. 2003). To visualize the direction of gene flow, we used the probabilities of each individual belonging to one cluster or another from STRUCTURE and used them to construct a pie chart per individual and plotted them on a map with geographic coordinates using QGis v.1.8.0 software (www.qgis.org).

Shared allele distances (Chakraborty \& Jin 1993, Jin \& Chakraborty 1994) were computed between individuals and were used to build a neighbor-joining (NJ) tree using the software POPULATIONS v.1.2.32 (Langella 2002), with 1000 bootstrap replications. This method has been used to identify subpopulations and locate unknown individuals to their subpopulation of origin in other carnivore species (Manel et al. 2004).

To evaluate the correlation between geographic and genetic distances, we applied a Mantel (1967) test. We used GENEALEX6 to compute both distance matrices and a Mantel test to assess the correlation between the 2 matrices (Peakall \& Smouse 2006).

Within clusters, we analyzed the inbreeding index $F_{\text {IS }}$ and diversity within individuals (1 - Qintra) and among individuals within samples (1 - Qinter) using GENEPOP (Raymond \& Rousset 1995).

\section{Bolivian samples}

We used GENECAP (Wilberg \& Dreher 2004) to identify capture histories and to determine the number of maned wolves that may have been resampled from multiple scats. The samples collected in Bolivia were mostly from feces $(81 \%)$, and it is possible that the same individual may be recaptured. Therefore, the software detects matching genotypes with a match probability of 0.01 and assuming that individuals could be siblings (Wilberg \& Dreher 2004). The sibling probability of identity and the Hardy-Weinberg probability of identity were assessed. Sibling probability values $<0.05$ are considered acceptable (Woods et al. 1999).

\section{Captive stocks}

$F_{\text {ST }}$ among captive stocks and its statistical significance were estimated with ARLEQUIN v.3.11 (Excoffier \& Lischer 2010). The inbreeding coefficients for each stock and the overall $F_{\mathrm{IS}}$ and $F_{\mathrm{IT}}$ respectively were estimated using GENEPOP (Raymond \& Rousset 1995). The contribution of each stock to the global genetic diversity was assessed by the methods de- 
scribed by Caballero \& Toro (2002) and Petit et al. (1998). The method implemented in Caballero \& Toro (2002) relies on maintaining the maximum global gene diversity, minimizing the average global molecular co-ancestry, whereas the method in Petit et al. (1998) evaluates the AR contribution of each stock to the overall dataset. Both contributions were computed using MOLKIN 3.0 (Gutiérrez et al. 2005).

Relatedness coefficients and pedigree relationships between animals as well as mean relatedness coefficients per stock and their standard deviations were calculated using the software ML-RELATE (Kalinowski et al. 2006).

We assessed the assignment of captive samples into wild populations with STRUCTURE (Pritchard et al. 2000). This analysis was conducted for the loci that successfully amplified and that were under linkage equilibrium for both datasets. The number of $K$ ranged from 1 to 7 with 5 replicates, 10000 burn-in period and 200000 iterations for MCMC. The most likely number of clusters was selected using the methodology described above for wild populations.

\section{RESULTS}

\section{Genetic analysis of Bolivian samples}

A total of 23 individuals were identified out of the 31 scat and 6 blood samples collected in Bolivia. Both sample types were included in the analysis because we also wanted to verify that the scats included in the genetic analysis were from different individuals and to eliminate those that could belong to a previously captured maned wolf. The sibling probability of identity and the Hardy-Weinberg probability of identity were $\mathrm{P}(\mathrm{ID})_{\mathrm{SIBS}}=3.1 \times 10^{-4}$ and $\mathrm{P}(\mathrm{ID})=1.14 \times 10^{-9}$ respectively. For the remaining analysis, we only used the 23 samples identified as different individuals.

\section{Genetic diversity and differentiation in the wild population}

Of the 12 microsatellite loci screened, 1 locus (FH2328) showed lower amplification success in fecal DNA samples and was excluded from further analysis, leaving 11 polymorphic microsatellite loci for the remaining analyses of the wild population. The allelic diversity and PIC values for each locus on both clusters are shown in Table 2. The mean diversity in the 11 analyzed loci was $11.82(\mathrm{SD}=6.997)$. The global PIC value was $0.741(\mathrm{SD}=0.178)$ and overall

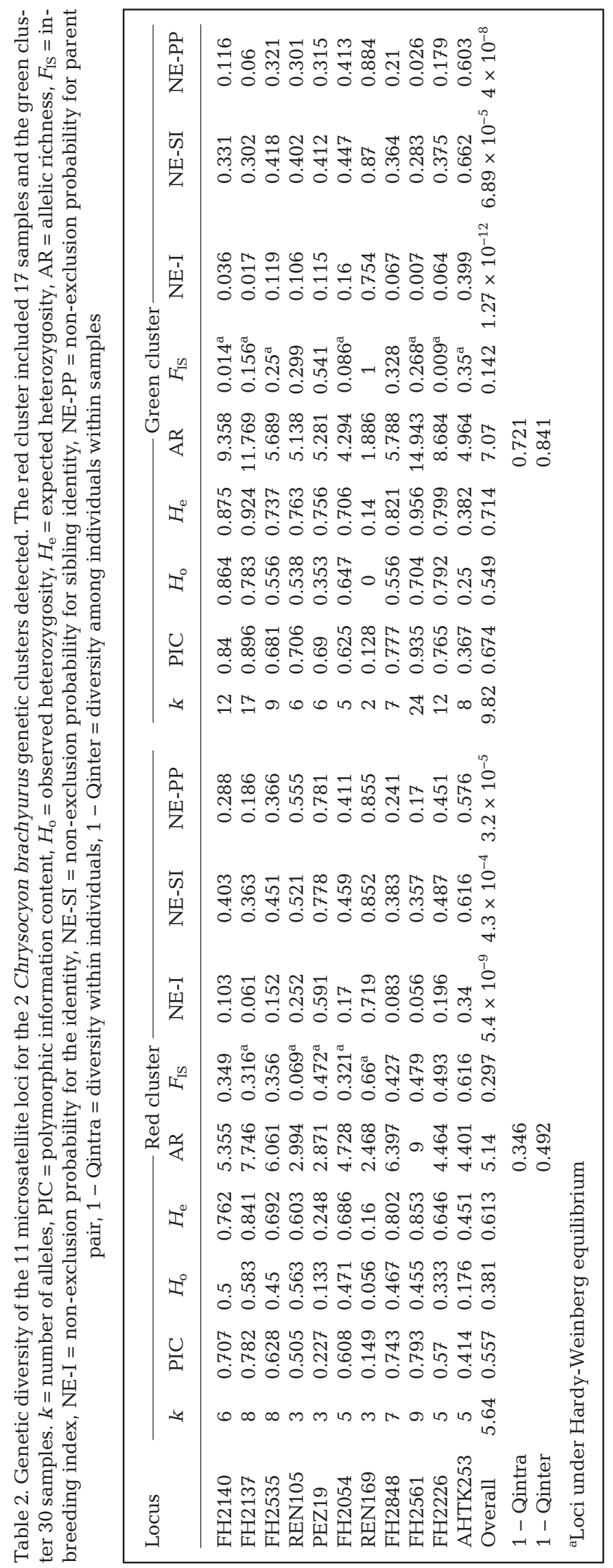


A

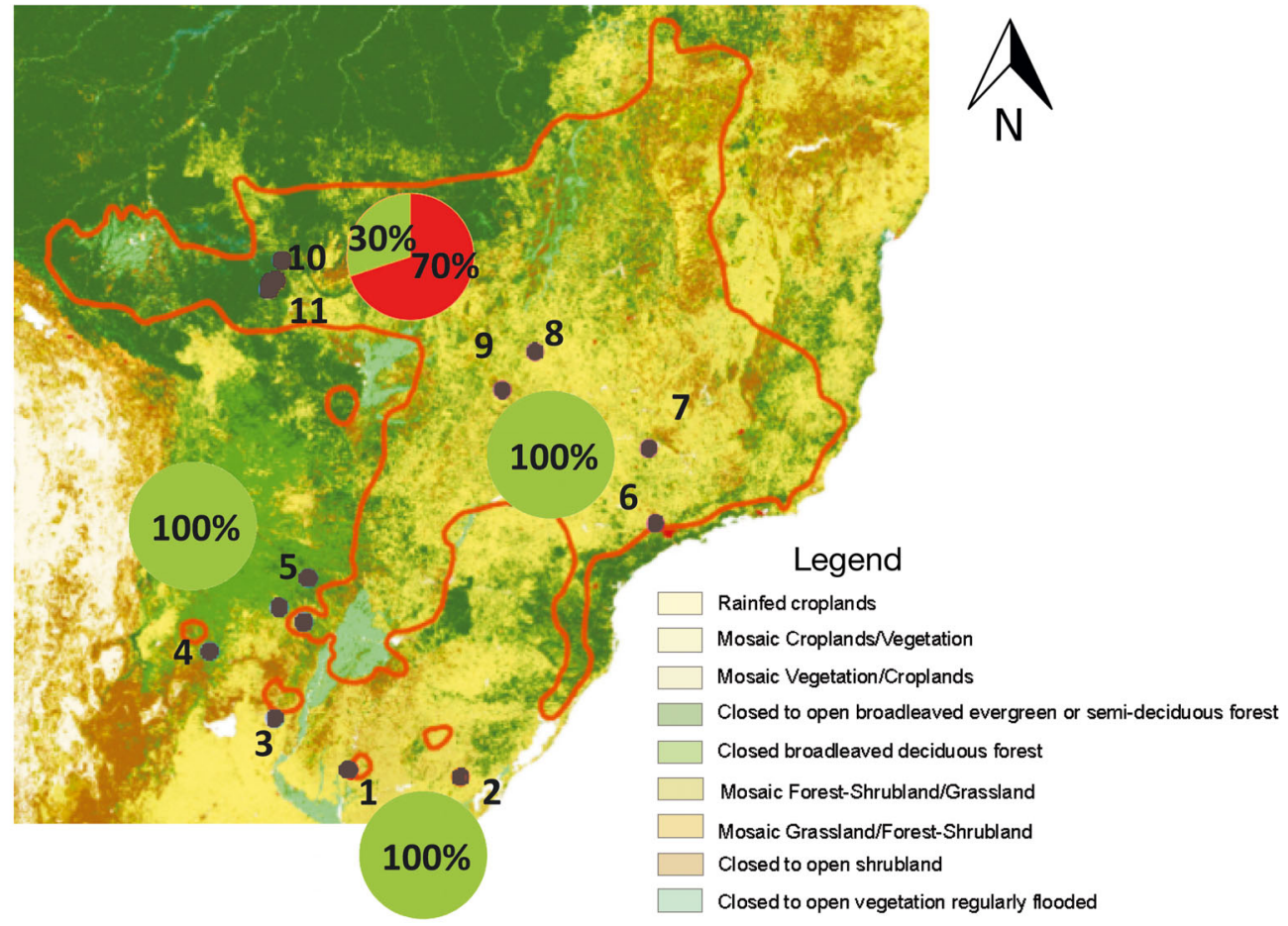

B
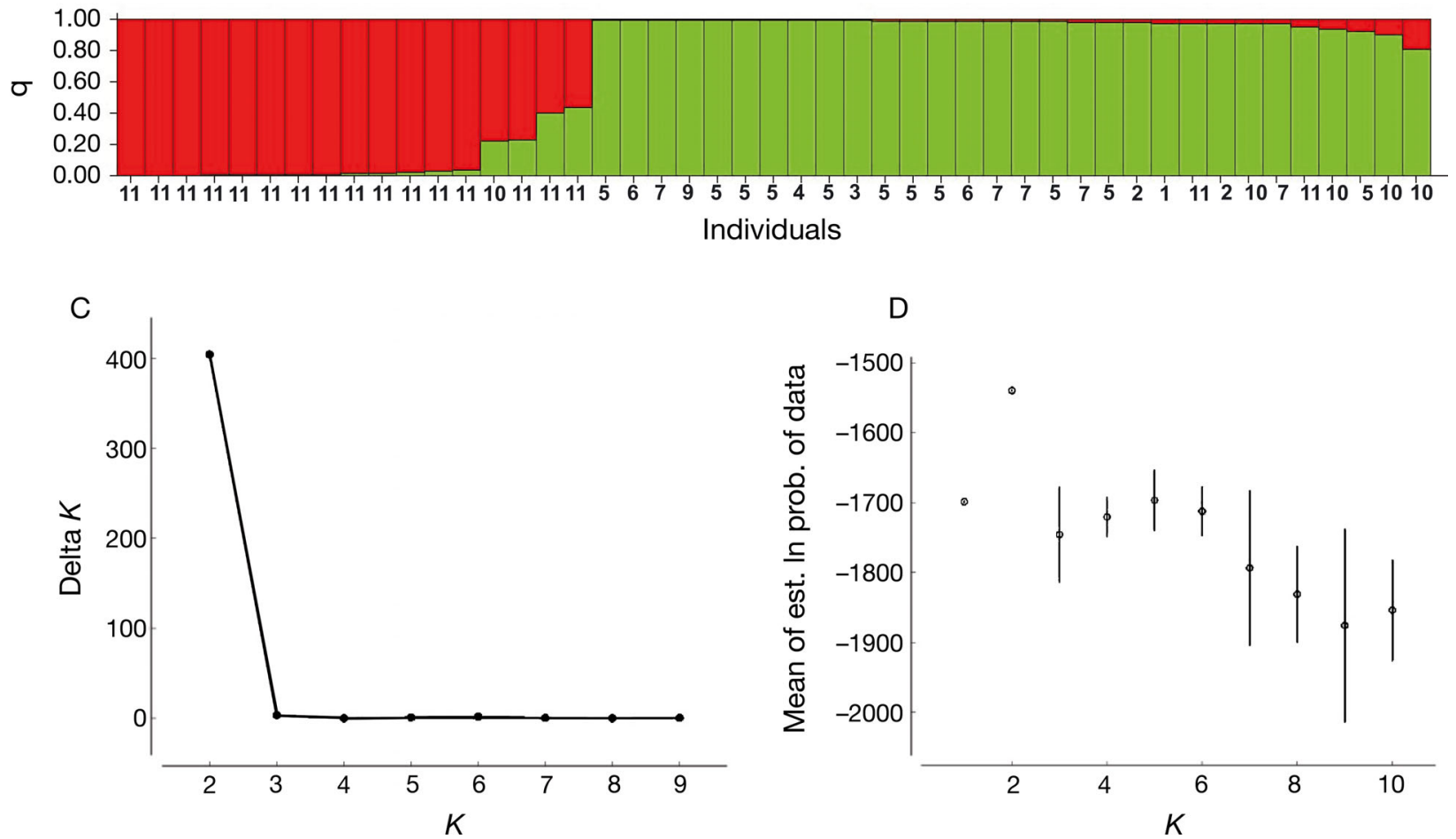

Fig. 1. (A) Land cover for Chrysocyon brachyurus in South America. Boundary represents species range. Numbered dots indicate sampling locations: Uruguay: 1 = Rio Negro, 2 = Cerro Largo; Argentina: 3 = Santa Fé, 4 = Santiago del Estero, 5 = Formosa and Chaco; Brazil: $6=$ Gaia, $7=$ Franca, $8=$ Yatai, $9=$ Chapada do Sul $;$ Bolivia: $10=$ Mangabalito, $11=$ El Refugio and National Park Noel Kempff. Pie charts show proportions of genetic clusters in each group of localities sampled. (B) STRUCTURE bar plot screening 2 genetic clusters. Each line represents a distinct maned wolf. Green and red for each cluster in bar plots are consistent with pie charts in (A). (C) Delta $K$ rate of change in log probability and (D) posterior probability (mean \pm SD) of the data $(\operatorname{lnP}(K))$ as a function of $K$ (clusters) in Bayesian STRUCTURE analysis 
expected heterozygosity $\left(H_{\mathrm{e}}\right)$ was $0.699(\mathrm{SD}=0.160)$. Most of the loci showed departures from HWE, and some comparisons in the LD test presented slight deviations after Bonferroni corrections. These departures were likely due to the Wahlund effect (Allendorf \& Luikart 2007). Therefore, we subsequently analyzed each of the 2 genetic clusters that were identified in the STRUCTURE analysis separately (see next paragraph and Table 2).

Bayesian STRUCTURE analysis showed that $K=$ 2 was the most likely number of clusters using $\ln \mathrm{P}(K)$ and Delta $K$ approximations (Fig. 1). One cluster includes only samples from Bolivia (which we call the 'red cluster'), while the other cluster includes samples from all of the sampled localities, including $30 \%$ of the individuals from Bolivia that are admixed ('green cluster') (Fig. 1). The same STRUCTURE analysis pattern was obtained using a dataset which excluded closely related individuals from Bolivia; thus this pattern is not a signature of sampled related animals. The $F_{\mathrm{ST}}$ genetic differentiation index between clusters was 0.187 and it was statistically significant $(p<0.05)$. The effective number of migrants between genetic clusters by the private allele and $F_{\mathrm{ST}}$ methods were 1.364 (mean sample size $=19.9$, mean frequency of private alleles $=0.074$ ) and 1.087 respectively. The distribution pattern of mixed or introgressed individuals plotted in Fig. 2 shows they are only present in samples from Bolivia. This suggests that the direction of gene flow is into Bolivia from the other geographic regions.
After Bonferroni correction, 5 loci were under HWE in the red cluster exclusively and 7 in the green cluster (Table 2). HWE deviations were detected in loci with positive $F_{\text {IS }}$ values (Table 2), indicating a deficiency of heterozygotes compared with HWE expectations (Waples 2015). LD was only significant between 2 pairs of loci in the cluster including samples from different localities (AHTK253-FH2848; AHTK253-FH2535). The non-exclusion probabilities for the identity of parent pairs and sibs on both clusters revealed that our markers had enough statistical power to conduct kinship and to reliably distinguish individuals (Table 2). Our sample sizes were small in some of our sampled localities; thus, caution is needed when comparing allelic diversity and heterozygosity results (Hale et al. 2012). Estimates of genetic diversity for these 2 clusters showed that the red cluster had lower overall AR and $H_{0}$ values than the green cluster $\left(H_{0}=0.613\right.$ vs. $0.714 ; \mathrm{AR}=5.14$ vs. 7.14$)$ (Table 2). The $t$-test for AR and $H_{\mathrm{o}}$ showed values of probability of 0.074 and 0.047 respectively; thus the mean values of AR are not statistically different between the clusters.

The NJ tree obtained showed 2 groups of Bolivian maned wolves and 1 small group including some animals from Argentina (Fig. 3). The correlation coefficient for the Mantel test was $0.095(p=0.19)$.

Values for the inbreeding coefficient $F_{\text {IS }}$ were highest for the cluster that includes samples from Bolivia (Table 2). Diversity within individuals (1 - Qintra) was lower than among individuals within samples (1 - Qinter) in each cluster (Table 2).

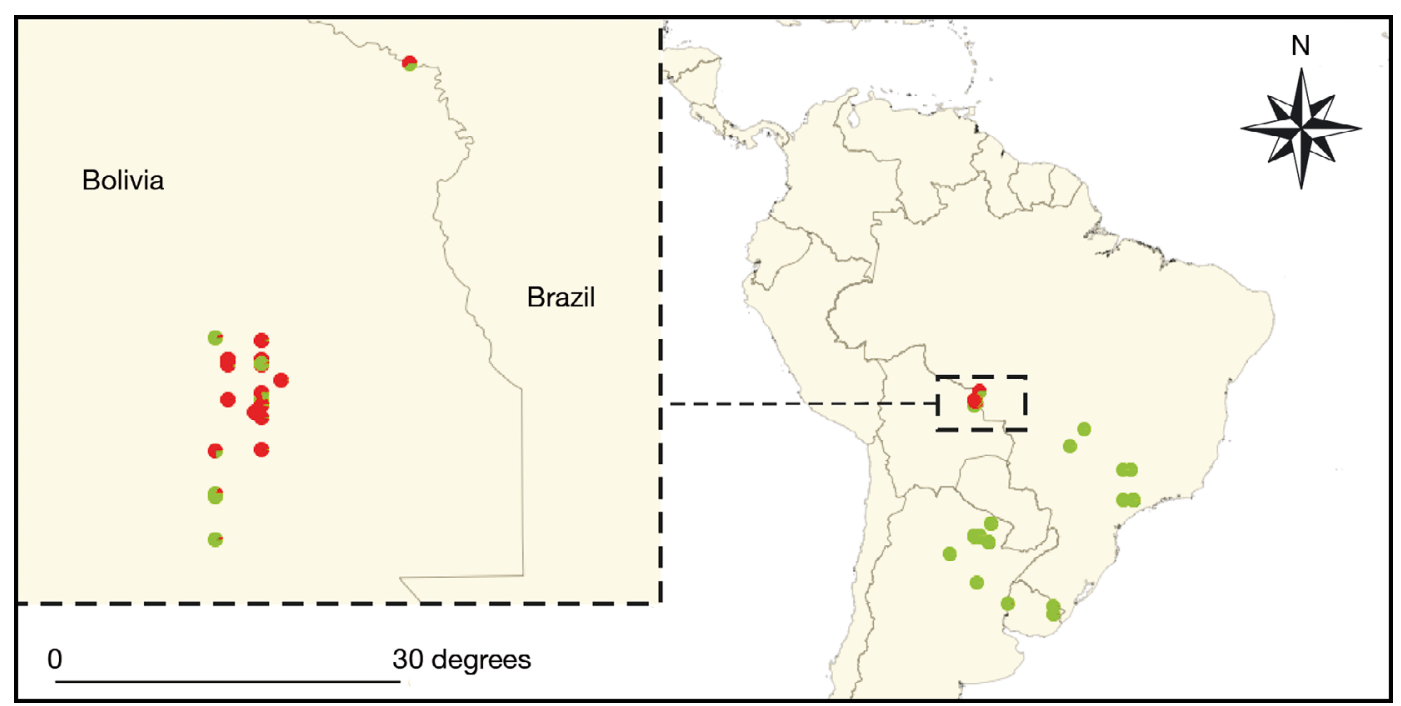

Fig. 2. Plots of pie chart probabilities per individual Chrysocyon brachyurus. STRUCTURE probabilities for each individual belonging to the red or green cluster were used to construct a pie chart per individual, these were then plotted on a map of South America with geographic coordinates (inset: border between Bolivia and Brazil) 


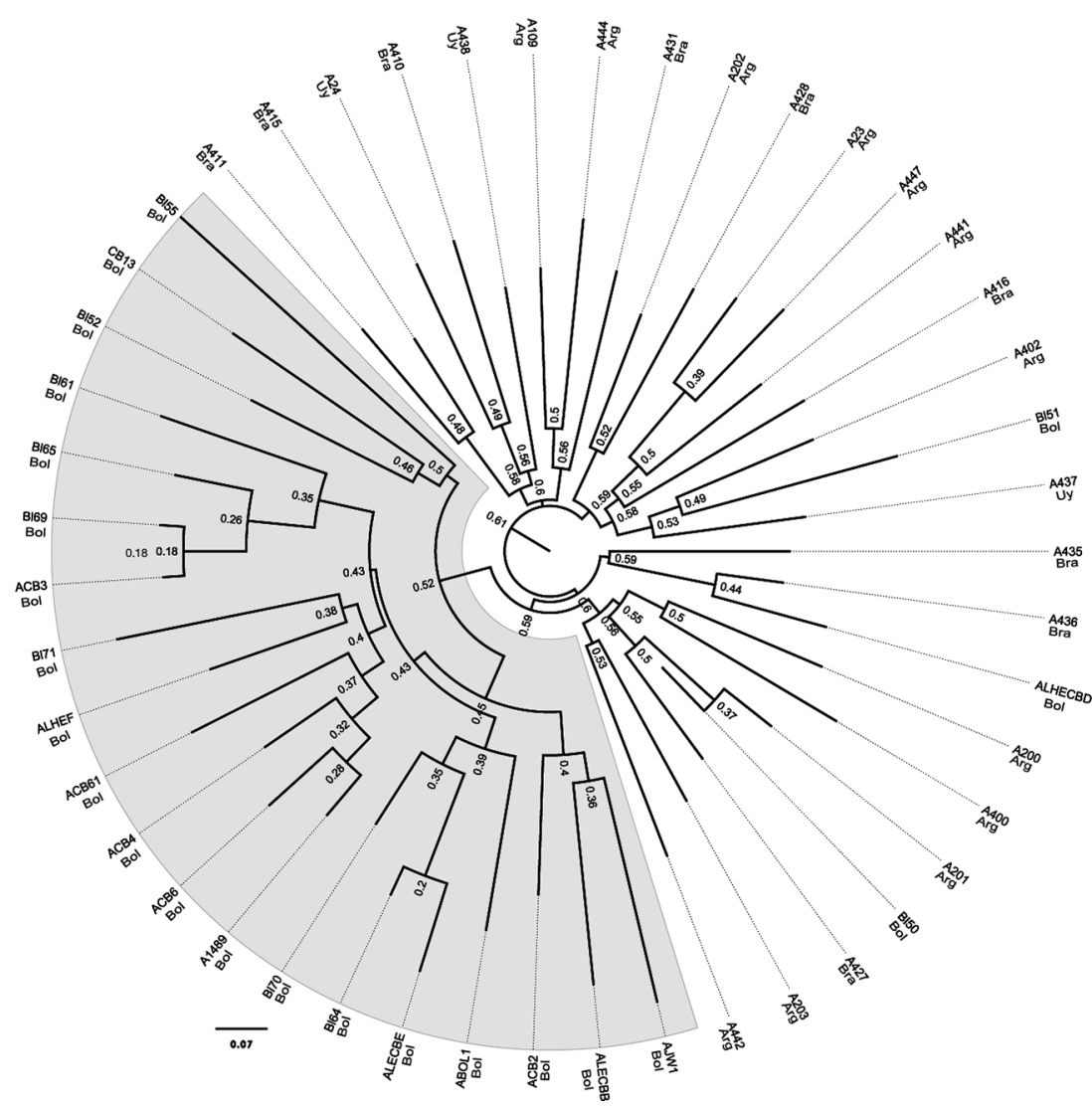

Fig. 3. Neighbor-joining tree computed using shared allele distance for wild Chrysocyon brachyurus. Bootstrap values calculated over 1000 replications. Gray shading shows 2 groups that include only samples from Bolivia (Bol). Arg = Argentina, Bra $=$ Brazil, Uy = Uruguay

\section{Genetic diversity and differentia- tion in captive population}

For the captive population, most of the samples yielded quality DNA and allowed us to analyze all 12 polymorphic loci. This entire captive stock yielded a mean allelic diversity of $9.42(\mathrm{SD}=5.367)$, with global $H_{\mathrm{e}}$ and PIC values of 0.75 $(\mathrm{SD}=0.198)$ and $0.707(\mathrm{SD}=0.205)$ respectively (Table 3 ). Overall nonexclusion probabilities of identity $\left(\mathrm{NE}-\mathrm{I}=1.34 \times 10^{-14}\right)$, for parent pairs (NE-PP $\left.=2.35 \times 10^{-9}\right)$ and sibs $\left(\mathrm{NE}-\mathrm{SI}=1.63 \times 10^{-5}\right)$ had enough statistical power to conduct identity and kinship analyses. All the loci were in HWE for each stock after Bonferroni corrections (Table 3). In addition, we did not detect inbreeding signals whether we analyzed the captive stocks separately or as a single group (Table 3 ). None of the pairwise comparisons of loci within stock were in LD after Bonferroni corrections.

Pairwise comparisons of $F_{\mathrm{ST}}$ values suggest that the USA stock is significantly differentiated from

Table 3. Genetic variability of Chrysocyon brachyurus captive stocks. GD = global gene diversity, AR Contrib = allelic richness contribution, nd = not done. See Table 2 for other abbreviations

\begin{tabular}{|c|c|c|c|c|c|c|c|c|c|c|c|c|c|c|c|}
\hline \multirow[t]{2}{*}{ Locus } & \multirow[b]{2}{*}{$k$} & \multirow[b]{2}{*}{$H_{\mathrm{o}}$} & \multicolumn{3}{|c|}{ - Argentina } & \multirow[b]{2}{*}{$k$} & \multirow[b]{2}{*}{$H_{\mathrm{o}}$} & \multicolumn{2}{|c|}{ - Brazil } & \multirow[b]{2}{*}{$F_{\mathrm{IS}}$} & \multirow[b]{2}{*}{$k$} & \multirow[b]{2}{*}{$H_{\mathrm{o}}$} & \multirow{2}{*}{$\begin{array}{l}-\mathrm{US} \\
\mathrm{H}_{\mathrm{e}}\end{array}$} & \multirow{2}{*}{$\mathrm{A}-\mathrm{PIC}$} & \multirow[b]{2}{*}{$F_{\mathrm{IS}}$} \\
\hline & & & $H_{\mathrm{e}}$ & PIC & $F_{\mathrm{IS}}$ & & & $H_{\mathrm{e}}$ & PIC & & & & & & \\
\hline FH2140 & 7 & 0.667 & 0.810 & 0.736 & $0.186^{\mathrm{a}}$ & 9 & 1 & 0.868 & 0.805 & $-0.161^{\mathrm{a}}$ & 3 & 0.833 & 0.621 & 0.477 & $-0.389^{a}$ \\
\hline FH2137 & 9 & 0.889 & 0.915 & 0.850 & $0.030^{\mathrm{a}}$ & 10 & 1 & 0.923 & 0.874 & $-0.077^{\mathrm{a}}$ & 3 & 0.833 & 0.667 & 0.535 & $-0.282^{\mathrm{a}}$ \\
\hline FH2328 & 5 & 1 & 0.767 & 0.679 & $-0.333^{\mathrm{a}}$ & 6 & 0.778 & 0.83 & 0.753 & $0.066^{\mathrm{a}}$ & 2 & 0.333 & 0.303 & 0.239 & $-0.111^{\mathrm{a}}$ \\
\hline FH2535 & 5 & 0.875 & 0.775 & 0.679 & $-0.139^{a}$ & 6 & 0.9 & 0.842 & 0.770 & $-0.072^{\mathrm{a}}$ & 3 & 0.833 & 0.712 & 0.579 & $-0.191^{\circ}$ \\
\hline FH2848 & 6 & 0.556 & 0.824 & 0.743 & $0.338^{\mathrm{a}}$ & 6 & 0.727 & 0.823 & 0.753 & $0.12^{\mathrm{a}}$ & 2 & 0.4 & 0.356 & 0.269 & $-0.143^{a}$ \\
\hline REN105 & 6 & 0.6 & 0.816 & 0.743 & $0.275^{\mathrm{a}}$ & 5 & 0.455 & 0.719 & 0.635 & $0.378^{\mathrm{a}}$ & 2 & 0.4 & 0.356 & 0.269 & $-0.143^{\mathrm{a}}$ \\
\hline PEZ19 & 2 & 0.5 & 0.530 & 0.368 & $0.062^{\mathrm{a}}$ & 3 & nd & 0.667 & 0.535 & 1 & 2 & 0.333 & 0.333 & 0.239 & nd \\
\hline FH2561 & 10 & 0.750 & 0.917 & 0.845 & $0.192^{\mathrm{a}}$ & 12 & 1 & 0.947 & 0.891 & $-0.058^{\mathrm{a}}$ & 2 & 0.667 & 0.533 & 0.346 & $-0.333^{a}$ \\
\hline FH2226 & 8 & 0.7 & 0.779 & 0.714 & $0.106^{\mathrm{a}}$ & 8 & 0.909 & 0.853 & 0.789 & $-0.069^{\mathrm{a}}$ & 4 & 1 & 0.821 & 0.667 & $-0.263^{a}$ \\
\hline FH2054 & 4 & 0.778 & 0.634 & 0.539 & $-0.244^{\mathrm{a}}$ & 4 & 0.750 & 0.675 & 0.570 & $-0.12^{\mathrm{a}}$ & 4 & 1 & 0.8 & 0.620 & $-0.333^{\mathrm{a}}$ \\
\hline REN169 & 1 & nd & nd & nd & nd & 2 & 0.091 & 0.091 & 0.083 & nd & 1 & nd & nd & nd & nd \\
\hline AHTK253 & 3 & 0.556 & 0.529 & 0.449 & $-0.052^{\mathrm{a}}$ & 3 & 0.273 & 0.255 & 0.228 & $-0.071^{\mathrm{a}}$ & 1 & nd & nd & nd & nd \\
\hline Overall & 5.5 & 0.715 & 0.691 & 0.612 & $0.0614^{\mathrm{a}}$ & 6.17 & 0.717 & 0.709 & 0.641 & $0.051^{\mathrm{a}}$ & 2.42 & 0.663 & 0.458 & 0.353 & $-0.244^{\mathrm{a}}$ \\
\hline NE-I & & & $27 \times 10$ & & & & & $88 \times 10^{-}$ & & & & & $3.5 \times 10$ & & \\
\hline NE-SI & & & $.56 \times 10$ & & & & & $.7 \times 10^{-}$ & & & & & $4.7 \times 10$ & & \\
\hline NE-PP & & & $1 \times 10^{-6}$ & & & & & $.3 \times 10^{-}$ & & & & & $3.3 \times 10$ & & \\
\hline GD & & & 0.689 & & & & & 0.709 & & & & & 0.708 & & \\
\hline AR Contrib & & & -6.384 & & & & & -5.637 & & & & & 8.146 & & \\
\hline
\end{tabular}



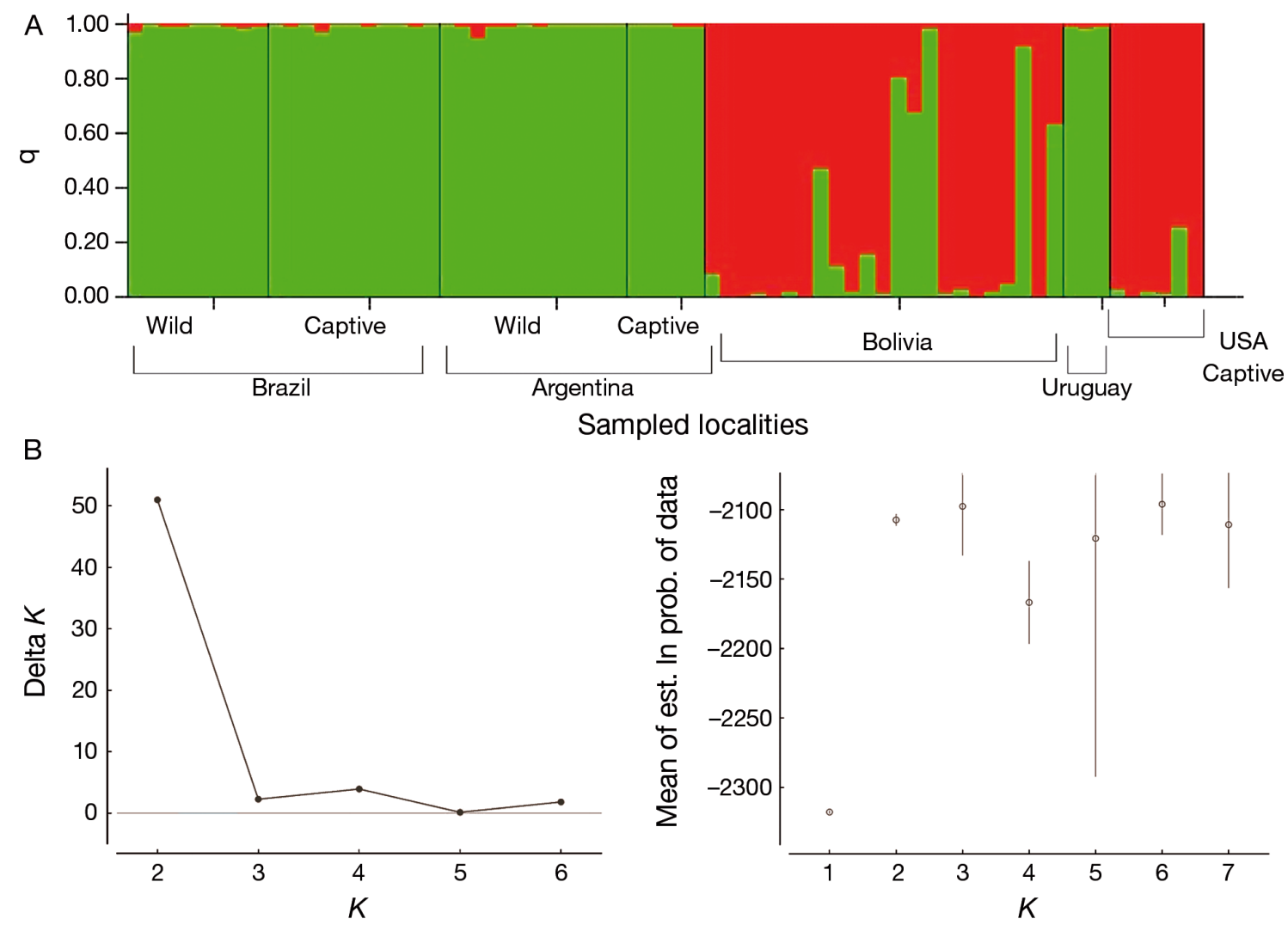

Fig. 4. Assignment patterns of Chrysocyon brachyurus captive stocks into wild clusters. (A) STRUCTURE bar plot for 2 genetic clusters. (B) Delta Krate of change in log probability and (C) posterior probability (mean \pm SD) of the data $(\operatorname{lnP}(K))$ as a function of $K$ (clusters). Red and green clusters are as for the wild populations (see Figs. $1 \& 2$ ). q: Fractional membership of each individual in each cluster

the others (mean $\left.F_{\mathrm{ST}}=0.631, \mathrm{SD}=0.117 ; \mathrm{p}<0.05\right)$. Pairwise comparisons between the Argentinean and Brazilian stocks revealed a significant $F_{\mathrm{ST}}$ value $\left(F_{\mathrm{ST}}=0.057 ; \mathrm{p}<0.05\right)$. The USA stock yielded a positive contribution to the global $\mathrm{AR}_{\text {; }}$ meanwhile, each stock had positive values $(0.69-0.71)$ in gene diversity. The total number of individuals in captivity included in this analysis also showed values of global genetic diversity of 0.734 (Table 3 ).

The mean relatedness coefficients for the Argentinean and Brazilian captive animals were low and ranged between $0.040(\mathrm{SD}=0.081)$ and $0.097(\mathrm{SD}=$ 0.136 ) respectively, whereas for the USA captive animals it was $0.557(\mathrm{SD}=0.152)$. We were also able to determine the kinship relationships of animals in each stock. The Argentinean captive stock had 4 pairs of animals that were related at the half-sib (HS) level and in the Brazilian stock 14 pairs were related at the HS level. Furthermore, the Brazilian stock had a pair of animals related at the parent-offspring level and another pair of animals related at the full-sib level. The USA stock correctly yielded the expected levels of relationship between them, given that we were aware that these animals constituted a family group made up of 4 full-sibs and the 2 breeding parents. We used this family group as a control for testing the power of our microsatellite loci panel to conduct kinship analysis.

The most likely number of clusters using both approximations was $K=2$ (Fig. 4). The captive stocks from Brazil and Argentina were assigned into the same cluster that included wild samples from each country. However, the USA stock was grouped within wild maned wolves from Bolivia.

\section{DISCUSSION}

\section{Genetic diversity and structure of the wild population}

Despite the fact that the few remaining populations of maned wolves currently persist in fragmented habitats, we found that they retain moderate levels of 
genetic variability (mean $H_{\mathrm{e}}=0.66$ ) compared to previous studies on other endangered canids such as the Ethiopian wolf (mean $H_{\mathrm{e}}=0.47$ ) (Gottelli et al. 2013) and more abundant canids such as Arctic foxes (mean $H_{\mathrm{e}}=0.78$ ) (Carmichael et al. 2007). Additionally, previous microsatellite analyses based on small samples from Brazilian maned wolf populations found similar levels of heterozygosity (Fontoura-Rodrigues et al. 2008, Lion et al. 2011, Do Passo Ramalho et al. 2014). Genetic diversity is based on allelic frequencies, and therefore it is important to have an adequate sample size representative of each population. As suggested by Hale et al. (2012), increasing sample sizes will provide more precise estimates of genetic variability, and if at all possible, future efforts should focus on obtaining genetic diversity estimates using larger sample sizes from more localities. On the other hand, the geographic coordinates for some wild populations with one word in the IUCN species range boundaries used in Fig. 1 need to be updated, as some sampled areas (dots in Fig. 1A) are outside these boundaries.

In this study, we attempted to use the same samples included in a study that previously assessed the genetic variability of maned wolves using mtDNA markers (González et al. 2015a); however, some samples had to be excluded due to low amplification success rate for microsatellite loci compared to mtDNA (Pääbo et al. 1989). Nevertheless, even though we successfully included many of the samples across the same geographic region and although the most frequent haplotypes were represented, a comparison of our results showed somewhat discordant patterns with those obtained using mtDNA by González et al. (2015a). In their mtDNA study, 4 conservation units were identified: unit 1 grouped the Argentinean populations; unit 2 the Bolivian populations; unit 3 the Brazilian populations; and unit 4 the Uruguayan samples. In contrast, our microsatellite analysis only detected 2 genetic clusters. One of these clusters (the red cluster) included most of the samples from Bolivia, and the other (the green cluster) grouped a few individuals from Bolivia with the rest from all of the other localities that were sampled (Fig. 1).

Some samples collected in Bolivia that are grouped in the green cluster have a mitochondrial haplotype that is exclusively found in Bolivia (haplotype F), and the red cluster has samples with haplotypes B and D that are widely distributed across the species distribution range. The discordant patterns obtained with mitochondrial and nuclear microsatellite markers could be due to substantial differences in mode of inheritance and evolutionary rates (Freeland 2005). In this case, we propose that the higher levels of genetic structure revealed by the mtDNA markers are likely the result of female maned wolves being more philopatric; thus mtDNA yields higher levels of genetic structure because of its matrilineal inheritance (Avise 1995). In fact, ecological studies in Bolivia revealed that young female maned wolves are more philopatric than males (Emmons et al. 2012). Further, greater differentiation can be detected with mtDNA markers because the effective population size is 4 times smaller than nuclear markers (Natoli et al. 2008). Accordingly, the lower levels of genetic structure revealed by nuclear microsatellite markers support the fact that males may be dispersing larger distances and mediating greater levels of gene flow between populations.

Our microsatellite results suggest that there is greater connectivity between some conservation units than that previously described based on mtDNA (Argentina-Brazil-Uruguay, and Bolivia). These could be caused by recent changes in land use. For example, the modern agriculture expansion in the Brazilian Cerrado (the main habitat for maned wolves) began around 1950 (Silva et al. 2006), entailing a radical change in the landscape matrix. We note that the Bolivian samples were collected from the border with Brazil, and that radio-collared maned wolves readily swam across a $50 \mathrm{~m}$ wide river (Emmons 2012). The time lag between the occurrence of landscape changes and the appearance of a genetic structure signature for species with dispersal abilities $>10 \mathrm{~km}$ is about 1-3 generations (Anderson et al. 2010, Landguth et al. 2010). This is in agreement with a recent but detectable change in landscape matrix for maned wolf populations assessed here.

Although the major threat to this species is habitat conversion into farm and ranch lands (De Paula et al. 2008), maned wolves can forage in croplands (Kawashima et al. 2007, Vynne et al. 2014). Moreover, they can disperse through cultivated lands, connecting populations that were previously thought to be isolated (Kawashima et al. 2007). They may tolerate stress and negative influences of human interaction as long as they have water supplies and vegetation for resting and denning, as well as for thermoregulation (Vynne et al. 2014).

Microsatellite data revealed that the samples from Bolivia have genetic signatures from 2 clusters, one exclusively found in maned wolves from Bolivia (red cluster) and the other shared or admixed with samples from Brazil, Argentina and Uruguay (green cluster) (Fig. 2). This pattern could be the result of recent migrants from Brazil into Bolivia. The Bolivian population substructure could be explained by a partial 
isolation and subsequent reduction of gene flow. This hypothesis requires further analysis about the causes and timing of isolation and gene flow. Currently, deforestation of the Cerrado is rapidly fragmenting the populations. The interpretation of the vegetation changes in the Neotropics during the last glaciation period has been a matter of controversy (de Freitas et al. 2001). A study using carbon isotope records of vegetation at the border of the Brazilian states of Amazonas and Rondonia reported 3 stages: a wetter forest phase between 17000 and $9000 \mathrm{yr}$ BP, a savanna expansion between 9000 and 3000 yr BP, followed by the current forest expansion (de Freitas et al. 2001). On the other hand, results obtained through analysis of pollen and climate variables in the Noel Kempff Mercado National Park (NKMNP) in Bolivia, where our Bolivian samples were collected, indicated a predominance of dry forest species, lianas and savanna woodland during the Pleistocene (Burbridge et al. 2004). Results obtained from maned wolf mtDNA suggest that the Bolivian population had demographic fluctuations, while Brazilian and Argentinean populations had a signal of demographic expansion in the mismatch distribution, but only in Brazil was this signature statistically significant (González et al. 2015a). Consequently, mtDNA analysis suggests that the vegetation changes in Bolivia might have affected maned wolf population dynamics (fluctuations). From the mtDNA data, the Bolivian and Brazilian conservation units showed gene flow levels of 2 migrants per generation (González et al. 2015a). However, in the present study, the remaining units showed approximately 1 migrant per generation by both approaches. At present, an extensive portion of cleared land separates Bolivian animals from those in Brazil (Muir \& Emmons 2012), and the latter authors considered it a threat to connectivity between populations. This division is concordant with our results because we have found reduced gene flow between the red and green clusters. Maned wolves in NKMNP are observed in upland and wetland savannas (Killeen et al. 2003, Emmons 2012), and studies on vegetation changes are consistent with a forest expansion during the Holocene (de Freitas et al. 2001, Burbridge et al. 2004). We propose that the isolation event revealed by the genetic signature by microsatellite loci is congruent with the Holocene forest expansion (separating Bolivian animals) and the subsequent limited gene flow is in agreement with the existence of a biodiversity corridor (mosaic of savanna and humid forest) connecting the northern limit of NKMNP to Brazilian populations (Killeen et al. 2003).
An alternative hypothesis for the observed pattern of genetic structure is that the maned wolves in Bolivia occupy a different habitat than maned wolves in other areas sampled. In Bolivia, Cerrado savannas and humid and deciduous forests are prevalent, whereas in the other areas, croplands are predominant (Fig. 1). Large and medium-sized carnivores with high mobility can cross most potential topographic barriers, minimizing the influences of geographic factors (Pilot et al. 2006).

The NJ tree shows separation of different groupings in Bolivia and Argentina. However, bootstrap values were low $(<0.5)$, and we could not find geographic concordance in the groupings sampled from Argentina or Bolivia (Fig. 3). Landscapes are spatially heterogeneous and dynamic; the correlation we used (Mantel test) did not consider the features that could affect animal movement (Spear et al. 2010).

Although maned wolves may tolerate and use cultivated lands, there is growing concern about their future in this changing matrix of land use. In studies conducted in the Brazilian Cerrado, females in croplands outside of protected areas showed lower levels of reproductive hormones (Vynne et al. 2014). Likewise, the rapid expansion of sugar cane production for biofuels will cause a decreasing survival rate for maned wolves, as they avoid that habitat (Vynne et al. 2014).

Our results can be incorporated with previous genetic studies to develop better-informed conservation plans that define genetically based management units for maned wolves. The earlier mtDNA study recognized 4 management units (González et al. 2015a). Our results are in concordance with the mtDNA data in support of maintaining the Bolivian population of maned wolves as a different management unit. In addition, we propose that the Bolivian population should be listed as a conservation priority. However, we should also point out that future studies should incorporate samples from other geographic regions such as Beni and Pampas del Heath savannas from Bolivia, and Paraguay, as samples from these localities could reveal levels of connectivity as well as other important population genetic diversity information for the conservation of maned wolves.

\section{Genetic variability and management of captive stocks}

Captive breeding is an important tool in species conservation programs, and one of its main goals is to preserve the maximum possible level of genetic vari- 
ability within a species (Pelletier et al. 2009, Witzenberger \& Hochkirch 2011). Captive breeding facilities have been increasingly implementing the use of microsatellite loci to better monitor the genetic diversity of captive stocks (Witzenberger \& Hochkirch 2011). Such studies have focused on obtaining estimates of allelic diversity, observed and expected heterozygosities and inbreeding coefficients (Witzenberger \& Hochkirch 2011).

Our analysis of the genetic diversity of captive maned wolves showed overall high levels of $H_{0}$ compared with values obtained from wild maned wolves in this study. This suggests well implemented reproductive management strategies and the retention of adequate levels of genetic variability within and among captive stocks. The USA stock proved to have a major AR contribution different from that of other stocks (Table 3). The assignment method showed that the captive maned wolves from NZP (Smithsonian Institution, Front Royal, VA, USA) are genetically more similar to those from wild populations in Bolivia. However, information obtained from the studbook regarding these animals states that the grandparents of the 2 adults of this family group derived from animals captured from wild populations in Brazil and not Bolivia. One possible explanation for this grouping could be that wild Brazilian animals from the populations where both maned wolves living in Front Royal were captured were not included in our wild dataset. This should be taken into account when exchanges between captive stocks are conducted for reproduction. Mating between animals from USA stock and other maned wolf stocks from Brazil could potentially lead to outbreeding depression because they could belong to different genetic groups. Interpopulation crosses could result in a loss of fitness because of the disruption of interactions between genes or between genes and environment. Such factors are concerns for captive breeding programs and translocation-reintroduction programs (Edmands 2007).

Acknowledgements. This work was supported by the Programa de Desarrollo de las Ciencias Básicas (PEDECIBA, Uruguay), Agencia Nacional de Investigación e Innovación (FCE_3_2011_1_6619, ANII, Uruguay), and the Smithsonian Conservation Biology Institute, Center for Conservation Genomics (Washington, DC, USA). L.H.E.'s research was supported by the Smithsonian Institution, the National Geographic Society, and the Wildlife Conservation Society. We thank Melissa Rodden, Nucharin Songsasen, Lisa Ware and Nancy McInerney for logistical support with lab protocols and samples at the Smithsonian Conservation Biology Institute. We thank the Smithsonian National Zoological Park, the Buenos Aires Zoo, La Plata Zoo, Belo Horizonte Zoo, Riberao Preto Zoo, the National History Museum of Uruguay, Enrique González, Jorge Cravino, Sharon Deem, Ellen Bronson, Sixto Angulo, Matthew Muir and Fernando Del Aguila for their contribution in the collection of samples. L.H.E.'s research in Bolivia was in collaboration with the Museo de Historia Natural Noel Kempff Mercado, Universidad Gabriel René Moreno, Santa Cruz, Bolivia, under permits from the Dirección General de Biodiversidad and the Servicio Nacional de Áreas Protegidas of the Estado Plurinacional de Bolivia.

\section{LITERATURE CITED}

Allendorf FW, Luikart G (2007) Conservation and the genetics of populations. Blackwell Publishing, Malden, MA

Anderson CD, Epperson BK, Fortin MJE, Holderegger R and others (2010) Considering spatial and temporal scale in landscape genetic studies of gene flow. Mol Ecol 19: 3565-3575

Avise JC (1995) Mitochondrial DNA polymorphism and a connection between genetics and demography of relevance to conservation. Conserv Biol 9:686-690

*Bos DH, Gopurenko D, Williams RN, DeWoody JA (2008) Inferring population history and demography using microsatellites, mitochondrial DNA, and major histocompatibility complex (MHC) genes. Evolution 62:1458-1468

Brookfield JFY (1996) A simple new method for estimating null allele frequency from heterozygote deficiency. Mol Ecol 5:453-455

* Burbridge RE, Mayle FE, Killeen TJ (2004) Fifty-thousandyear vegetation and climate history of Noel Kempff Mercado National Park, Bolivian Amazon. Quat Res 61: 215-230

Caballero A, Toro M (2002) Analysis of genetic diversity for the management of conserved subdivided populations. Conserv Genet 3:289-299

Carmichael LE, Krizan J, Nagy JA, Fuglei E and others (2007) Historical and ecological determinants of genetic structure in arctic canids. Mol Ecol 16:3466-3483

Cegelski CC, Waits LP, Anderson NJ (2003) Assessing population structure and gene flow in Montana wolverines (Gulo gulo) using assignment-based approaches. Mol Ecol 12:2907-2918

Chakraborty R, Jin L (1993) A unified approach to study hypervariable polymorphisms: statistical considerations of determining relatedness and population distances. In: Pena S (ed) DNA fingerprinting: state of the science. Birkhäuser, Springer, Basel, p 153-175

* Deem SL, Emmons LH (2005) Exposure of free-ranging maned wolves (Chrysocyon brachyurus) to infectious and parasitic disease agents in the Noel Kempff Mercado National Park, Bolivia. J Zoo Wildl Med 36:192-197

* de Freitas HA, Pessenda LCR, Aravena R, Gouveia SEM, de Souza Ribeiro A, Boulet R (2001) Late Quaternary vegetation dynamics in the southern Amazon Basin inferred from carbon isotopes in soil organic matter. Quat Res 55: 39-46

De Paula R, Medici P, Goncalves Morato R (2008) Maned wolf action plan. Icmbio, Brasilia

Dietz JM (1985) Chrysocyon brachyurus. Mamm Species 234:1-4

Do Passo Ramalho FDP (2011) Tamanho populacional de lobos- guará (Chrysocyon brachyurus) em uma área pro- 
tegida de cerrado no sudeste do Brasil. Masters dissertation, Universidade Federal de Sao Carlos

Do Passo Ramalho F, Miotto RA, Martins N, Galetti PM (2014) Maned wolf (Chrysocyon brachyurus) minimum population size and genetic diversity in a Cerrado protected area of southeastern Brazil revealed by fecal DNA analysis. Mammalia 78:465-472

Earl D, vonHoldt B (2012) Structure Harvester: a website and program for visualizing STRUCTURE output and implementing the Evanno method. Conserv Genet Resour 4:359-361

Edmands S (2007) Between a rock and a hard place: evaluating the relative risks of inbreeding and outbreeding for conservation and management. Mol Ecol 16: 463-475

Emmons LH (2012) The maned wolves of Noel Kempff Mercado National Park. Smithson Contrib Zool 639. Smithsonian Institution Scholarly Press, Washington, DC

Emmons LH, Chávez V, Del Aguila LF, Angulo S, Muir MJ (2012) Chapter 5. Social interactions and reproduction. In: Emmons LH (ed) The maned wolves of Noel Kempff Mercado National Park. Smithsonian Institution Scholarly Press, Washington, DC, p 57-75

Evanno G, Regnaut S, Goudet J (2005) Detecting the number of clusters of individuals using the software STRUCTURE: a simulation study. Mol Ecol 14:2611-2620

* Excoffier L, Lischer HEL (2010) Arlequin suite ver 3.5: a new series of programs to perform population genetics analyses under Linux and Windows. Mol Ecol Resour 10: 564-567

Fontoura-Rodrigues MLD, Eizirik E (2014) Evolutionary and conservation genetics of the maned wolf. In: ConsorteMcCrea AG, Santos EF (eds) Ecology and conservation of the maned wolf. Multidisciplinary perspectives. CRC: Taylor \& Francis Group, Boca Raton, FL, p 77-86

Fontoura-Rodrigues ML, Lima-Rosa CA, Tchaika L, Valdez FP and others (2008) Cross-amplification and characterization of 13 tetranucleotide microsatellites in multiple species of Neotropical canids. Mol Ecol Resour 8:898-900

Franco Berriel MR (2004) Genetic variability of the maned wolf (Chrysocyon brachyurus). Masters dissertation, University of Amsterdam

Freeland JR (2005) Molecular ecology. John Wiley \& Sons, Chichester

González S, Cosse M, Franco Berriel MR, Emmons LH and others (2015a) Population structure of mtDNA variation due to Pleistocene fluctuations in the South American maned wolf (Chrysocyon brachyurus, Illiger, 1815): management units for conservation J Hered 106:459-468

* González S, Mannise N, Repetto L, Maldonado JE (2015b) Sex determination of three Neotropical canids by high resolution melting analysis. Conserv Genet Resour 7: 643-645

Gottelli D, Sillero-Zubiri C, Marino J, Funk SM, Wang J (2013) Genetic structure and patterns of gene flow among populations of the endangered Ethiopian wolf. Anim Conserv 16:234-247

Goudet J (1995) FSTAT (version 1.2): a computer program to calculate F-statistics. J Hered 86:485-486

* Gutiérrez JP, Royo LJ, Álvarez I, Goyache F (2005) MolKin v2.0: a computer program for genetic analysis of populations using molecular coancestry information. J Hered 96:718-721

Hale ML, Burg TM, Steeves TE (2012) Sampling for microsatellite-based population genetic studies: 25 to 30 indi- viduals per population is enough to accurately estimate allele frequencies. PLOS ONE 7:e45170

Hedrick PW (2001) Conservation genetics: where are we now? Trends Ecol Evol 16:629-636

Jin L, Chakraborty R (1994) Estimation of genetic distance and coefficient of gene diversity from single-probe multilocus DNA fingerprinting data. Mol Biol Evol 11:120-127

Kalinowski ST (2005) HP-Rare: a computer program for performing rarefaction on measures of allelic diversity. Mol Ecol Notes 5:187-189

Kalinowski ST, Wagner AP, Taper ML (2006) ML-Relate: a computer program for maximum likelihood estimation of relatedness and relationship. Mol Ecol Notes 6:576-579

Kawashima R, Siqueira M, Mantovani J (2007) Dados do monitoramento da cobertura vegetal por NDVI na modelagem da distribuicao geográfica potencial do loboguará (Chrysocyon brachyurus). In: Annals XIII Simposio Brasileiro de Sensoriamento Remoto, Florianópolis, 21-26 April 2007. XIII SBSR, p 3983-3990

Killeen T, Siles T, Grimwood T, Tieszen L, Steininger M, Tucker C, Panfil S (2003) Habitat heterogeneity on a forest-savanna ecotone in Noel Kempff Mercado National Park (Santa Cruz, Bolivia): implications for the long-term conservation of biodiversity in a changing climate. In: Bradshaw GA, Marquet PA (eds) How landscapes change: human disturbance and ecosystem fragmentation in the Americas. Springer, Berlin, p 285-312

* Landguth E, Cushman S, Schwartz M, McKelvey K, Murphy M, Luikart G (2010) Quantifying the lag time to detect barriers in landscape genetics. Mol Ecol 19:4179-4191

Langella O (2002) POPULATIONS 1.2.32. Population genetic software (individuals or populations distances, phylogenetic trees). http://bioinformatics.org/ tryphon/ populations/ (accessed 29 Sep 2016)

*Lion MB, Eizirik E, Garda AA, Fontoura-Rodrigues ML, Guimaraes Rodriguez FH, Marinho-Filho JS (2011) Conservation genetics of maned wolves in a highly impacted area of the Brazilian Cerrado biome. Genetica 139:369-381

* Manel S, Bellemain E, Swenson J, Francois O (2004) Assumed and inferred spatial structure of populations: the Scandinavian brown bears revisited. Mol Ecol 13:1327-1331

Mannise N, Cosse M, Repetto L, Franco Berriel MR, Maldonado JE, González S (2012) Análisis genético sobre la presencia de aguará guazú (Carnivora, Mammalia) en Uruguay. Bol Soc Zool Urug 21:30-38

Mantel N (1967) The detection of disease clustering and a generalized regression approach. Cancer Res 27:209-220

* Marshall TC, Slate J, Kruuk LE, Pemberton JM (1998) Statistical confidence for likelihood-based paternity inference in natural populations. Mol Ecol 7:639-655

McKelvey KS (2008) GenCapture 1.4 help. Rocky Mountain Research Station, Fort Collins

*Moritz C (1994) Defining 'Evolutionarily Significant Units' for conservation. Trends Ecol Evol 9:373-375

*Moritz C (1995) Uses of molecular phylogenies for conservation. Philos Trans R Soc B 349:113-118

Moritz C (1999) Conservation units and translocations: strategies for conserving evolutionary processes. Hereditas 130:217-228

Muir MJ, Emmons LH (2012) Chapter 7. Conservation. In: Emmons LH (ed) The maned wolves of Noel Kempff Mercado National Park. Smithsonian Institution Scholarly Press, Washington, DC, p 91-115

Natoli A, Canadas A, Vaquero C, Politi E, Fernandez-Navarro P, Hoelzel AR (2008) Conservation genetics of the short- 
beaked common dolphin (Delphinus delphis) in the Mediterranean Sea and in the eastern North Atlantic Ocean. Conserv Genet 9:1479-1487

Navidi W, Arnheim N, Waterman M (1992) A multiple-tubes approach for accurate genotyping of very small DNA samples by using PCR: statistical considerations. Am J Hum Genet 50:347-359

Pääbo S, Higuchi R, Wilson AC (1989) Ancient DNA and the polymerase chain reaction. The emerging field of molecular archaeology. J Biol Chem 264:9709-9712

Palsbøll PJ, Bérubé M, Allendorf FW (2007) Identification of management units using population genetic data. Trends Ecol Evol 22:11-16

Paula RC, DeMatteo K (2016) Chrysocyon brachyurus. In: The IUCN Red List of Threatened Species, 2015:e.T4819 A82316878 (accessed 12 Apr 2016)

* Peakall ROD, Smouse PE (2006) Genalex 6: genetic analysis in Excel. Population genetic software for teaching and research. Mol Ecol Notes 6:288-295

Pelletier F, Reale D, Watters J, Boakes EH, Garant D (2009) Value of captive populations for quantitative genetics research. Trends Ecol Evol 24:263-270

Petit RJ, El Mousadik A, Pons O (1998) Identifying populations for conservation on the basis of genetic markers. Conserv Biol 12:844-855

Pilot M, Jedrzejewski W, Branicki W, Sidorovich VE, Jedrzejewska B, Stachura K, Funk SM (2006) Ecological factors influence population genetic structure of European grey wolves. Mol Ecol 15:4533-4553

Prates JPHdS (2008) Diversidade genética e historia evolutiva do lobo guará. PhD dissertation, Pontifícia Universidade Católica do Rio Grande do Sul, Porto Alegre

* Pritchard JK, Stephens M, Donnelly P (2000) Inference of population structure using multilocus genotype data. Genetics 155:945-959

Queirolo D, Moreira JR, Soler L, Emmons LH and others (2011) Historical and current range of the Near Threatened maned wolf Chrysocyon brachyurus in South America. Oryx 45:296-303

Raymond M, Rousset F (1995) GENEPOP (version 1.2): population genetics software for exact tests and ecumenicism. J Hered 86:248-249

Rice WR (1989) Analysing tables of statistical tests. Evolution 43:223-225

Rodden M, Rodrigues F, Bestelmeyer S (2004) Maned wolf Chrysocyon brachyurus (Illiger, 1815). In: Sillero-Zubiri C, Hoffmann M, Macdonald DW (eds) Canids: foxes, wolves, jackals and dogs: status survey and conservation action plan. IUCN/Species Survival Commission Canid Specialist Group, Gland, p 38-43

Rodrigues FM, Telles MP, Resende LV, Soares TN, DinizFilho JA, Jacomo AT, Silveira L (2006) Transferability of short tandem repeat markers for two wild canid species

Editorial responsibility: Mike Bruford,

Cardiff, UK inhabiting the Brazilian Cerrado. Genet Mol Res 5: 846-850

Salim DC, Akimoto AA, Carvalho CB, Oliveira SF, Grisolia CK, Moreira JR, Klautau-Guimaraes MN (2007) Genetic variability in maned wolf based on heterologous shorttandem repeat markers from domestic dog. Genet Mol Res 6:348-357

Silva J, Fariñas M, Felfili J, Klink C (2006) Spatial heterogeneity, land use and conservation in the cerrado region of Brazil. J Biogeogr 33:536-548

Slatkin M (1985) Gene flow in natural populations. Annu Rev Ecol Syst 16:393-430

K Smith DA, Ralls K, Hurt A, Adams B, Parker M, Maldonado JE (2006) Assessing reliability of microsatellite genotypes from kit fox faecal samples using genetic and GIS analyses. Mol Ecol 15:387-406

Spear SF, Balkenhol N, Fortin MJE, McRae BH, Scribner K (2010) Use of resistance surfaces for landscape genetic studies: considerations for parameterization and analysis. Mol Ecol 19:3576-3591

Taberlet P, Griffin S, Goossens B, Questiau S and others (1996) Reliable genotyping of samples with very low DNA quantities using PCR. Nucleic Acids Res 24:3189-3194

Taberlet P, Waits LP, Luikart G (1999) Noninvasive genetic sampling: look before you leap. Trends Ecol Evol 14: 323-327

*Van Oosterhout C, Hutchinson W, Wills DPM, Shipley P (2004) Micro-checker: software for identifying and correcting genotyping errors in microsatellite data. Mol Ecol Notes 4:535-538

Vanstreels R, Pessutti C (2010) Analysis and discussion of Maned wolf Chrysocyon brachyurus population trends in Brazilian institutions: lessons from the Brazilian studbook, 1969-2006. Int Zoo Yearb 44:121-135

* Vynne C, Booth RK, Wasser SK (2014) Physiological implications of landscape use by free-ranging maned wolves (Chrysocyon brachyurus) in Brazil. J Mammal 95:696-706

* Waples RS (2015) Testing for Hardy-Weinberg proportions: Have we lost the plot? J Hered 106:1-19

WWayne RK, Morin PA (2004) Conservation genetics in the new molecular age. Front Ecol Environ 2:89-97

*Wilberg MJ, Dreher BP (2004) Genecap: a program for analysis of multilocus genotype data for non-invasive sampling and capture-recapture population estimation. Mol Ecol Notes 4:783-785

*Witzenberger K, Hochkirch A (2011) Ex situ conservation genetics: a review of molecular studies on the genetic consequences of captive breeding programmes for endangered animal species. Biodivers Conserv 20:1843-1861

Woods JG, Paetkau D, Lewis D, McLellan BN, Proctor M, Strobeck C (1999) Genetic tagging of free-ranging lack and brown bears. Wildl Soc Bull 27:616-627

Wright S (1943) Isolation by distance. Genetics 28:114-138

Submitted: October 13, 2016; Accepted: September 5, 2017 Proofs received from author(s): October 31, 2017 